GIRENKO Yulia - Teacher, Separate Structural Subdivision «Nemyriv Professional College of Construction, Economics and Design VNAU» (22800, Nemyrov, 29, Gymnasium Str., e-mail: ugirenko1983@gmail.com).

ТОМАШУК Инна Викторовна - доктор философии с экономики, ассистент кафедры экономики и предпринимательской деятельности, Винницкий национальный аграрный университет (21008, г. Винница, ул. Солнечная, 3, e-mail: tomashuk.inna@ukr.net).

ТОМЧУК Елена Феликсовна - кандидат экономических наук, доцент, доцент кафедры анализа и статистики, Винницкий национальный аграрный университет (21008, г. Винница, ул. Солнечная, 3, e-mail: olenatomchuk@ukr.net).

ГИРЕНКО Юлия Васильевна - преподаватель, Обособленное структурное подразделение «Немировский профессиональный колледж строительства, экономики и дизайна ВНАУ» (22800, г. Немиров, ул. Гимназическая, 29, e-mail: ugirenko1983@gmail.com).

УДК 657:631.147

DOI: 10.37128/2411-4413-2021-2-15

\author{
ЗАКОНОДАВЧЕ \\ РЕГУЛЮВАННЯ \\ ОБЛІКУ \\ ОРГАНІЧНОГО \\ ВИРОБНИЦТВА В \\ УКРАÏHI
}

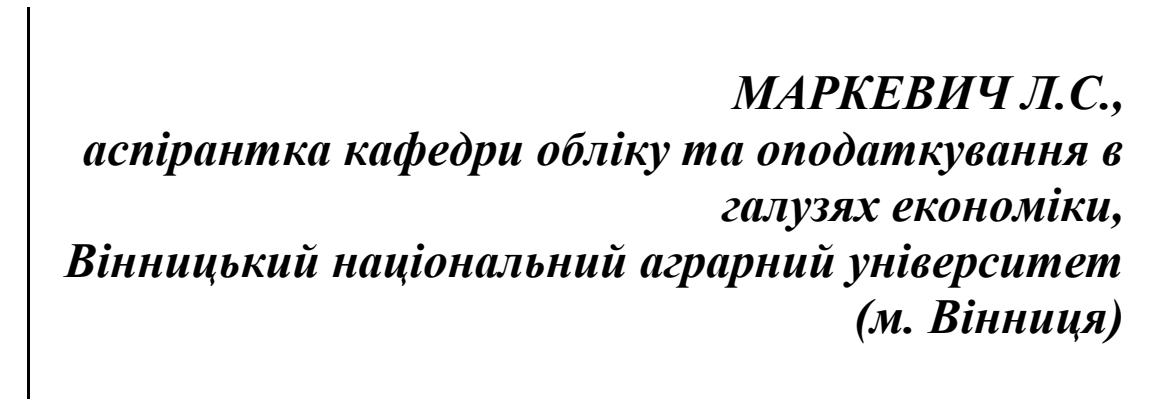

У статті проведено дослідження думок науковизів із актуальних питань обліку виробництвва органічної продукиії. Розкрито сучасний стан світового споживчого ринку екопродуктів, зазначено активне зростання попиту споживачів щуодо органічних продуктів. Досліджено правове регулювання органічного виробництва та розкрито різні погляди вчених щуодо напрямів удосконалення діючого законодавства в Украӥні. Представлено на законодавчому рівні закріплення змісту так званої «органіки». Виокремлено організацію ведення первинного обліку господарських операцій, пов'язаних із органічним землеробством на вітчизняних сільськогосподарських підприємствах. Розглянуто необхідність розробки типових форм документів та Методичних рекомендацій щуодо організації ведення обліку в умовах органічного виробництва в Україні. 3'ясовано основні галузі органічного виробництва в Україні. Представлено особливості та визначено недоліки формування облікової політики на «органічних підприємствах». Розглянуто перелік типової документації «органічних підприємств» із обліку виробництва органічної продукції рослинництва. Встановлено недосконалість нормативно-правової бази та відсутність належного інформаційного забезпечення, а також їх вплив на роботу «органічних підприємств». Підтверджено необхідність здійснення відображення у показниках фінансової звітності облікових даних про витрати на органічне виробництво та наявність і рух органічної сільськогосподарської продукиіі. За результатами дослідження визначено необхідність розробки методологічного інструментарію для обліку органічного виробництва. 3 розвитком органічного виробництва має бути належним чином організована система обліку, яка сприятиме забезпеченню користувачів своєчасною та достовірною інформацією про виробництво, зберігання та 
реалізацію органічної сільськогосподарської продукції.

Ключові слова: органічна продукція, органічне виробництво, облік органічної продукції, ринок органічної продукції, сертифікація органічної продукції, облік.

Табл.: 2. Рис.:2. Літ.: 16.

\title{
LEGISLATIVE REGULATION OF ORGANIC PRODUCTION ACCOUNTING IN UKRAINE
}

\author{
MARKEVICH LyUdmila, \\ Postgraduate Student of the Department of Accounting and Taxation \\ in the Fields of Economics, \\ Vinnytsia National Agrarian University \\ (Vinnytsia)
}

The article examines the opinions of scientists on topical issues of accounting for organic production. The current state of the world consumer market of eco-products is revealed, the active growth of consumer demand for organic products is noted. The legal regulation of organic production is studied, and different views of scientists on the directions of improvement of the current legislation in Ukraine are revealed. The consolidation of the content of the so-called «organic» is presented at the legislative level. The organization of primary accounting of economic operations related to organic farming on domestic agricultural enterprises is studied. The necessity of development of standard forms of documents and Methodical recommendations on the organization of accounting in the conditions of organic production in Ukraine is considered. The main branches of organic production in Ukraine are studied. Peculiarities and shortcomings in the formation of accounting policy at «organic enterprises» are presented. The list of standard documentation of «organic enterprises» on the account of production of organic crop products is considered. The imperfection of the regulatory framework and the lack of proper information support, as well as their impact on the work of «organic enterprises». The need to reflect in the indicators of financial statements accounting data on the costs of organic production and the availability and movement of organic agricultural products has been confirmed. According to the results of the study, the need to develop methodological tools for accounting for organic production was determined. With the development of organic production, the accounting system should be properly organized, which will help provide users with timely and accurate information on the production, storage and sale of organic agricultural products.

Key words: organic production, organic products, accounting of organic production, organic market, certification of organic production, accounting.

Table: 2. Fig. 2.: Lit.: 16.

\section{ЗАКОНОДАТЕЛЬНОЕ РЕГУЛИРОВАНИЕ УЧЕТА ОРГАНИЧЕСКОГО ПРОИЗВОДСТВА В УКРАИНЕ}

МАРКЕВИЧ Л.С., аспирантка кафедры учета и налогообложения в отраслях экономики, Винницкий национальный аграрный университет (2. Винница)

В статье проведено исследование мнений ученых по актуальным вопросам учета производства органической продукиии. Раскрыто современное состояние мирового потребительского рынка экопродуктов, указано активный рост спроса потребителей на 
органические продукты. Исследовано правовое регулирование органического производства и раскрыто разные взгляды ученых по направлениям совершенствования действуюшего законодательства в Украине. Представлено на законодательном уровне закрепления содержания так называемой «органики». Выделена организачия ведения первичного учета хозяйственных операчий, связанных с органическим земледелием на отечественных сельскохозяйственных предприятиях. Рассмотрено необходимость разработки типичних форм документов и Методических рекомендачий по организации ведения учета в условиях органического производства в Украине. Выяснено основные области органического производства в Украине. Представлень особенности и определень недостатки формирования учетной политики на «органических предприятиях». Рассмотрен перечень типовой документации «органических предприятий» по учету производства органической продукции растениеводства. Установлено несовершенство нормативно-правовой базы $u$ отсутствие надлежащего информачионного обеспечения, а также их влияние на работу «органических предприятий». Подтверждена необходимость осуществления отражение в показателях финансовой отчетности учетных данных о затратах на органическое производство, наличие и движение органической сельскохозяйственной продукиии. По результатам исследования определена необходимость разработки методологического инструментария для учета органического производства. С развитием органического производства нужно должным образом организовать систему учета, которая будет способствовать обеспечению пользователей своевременной и достоверной информацией о производстве, хранении и реализации органической сельскохозяйственной продукиии.

Ключевые слова: органическая продукция, органическое производство, учет органической продукции, рынок органической продукции, сертификация органической продукции, учет.

Табл.: 2. Рис.: 2. Лит.: 16.

Постановка проблеми. В умовах сьогодення сільське господарство сильно потерпає від великої кількості хімікатів, які активно використовуються у процесі виробництва сільськогосподарської продукції. Активне застосування синтетичних мінеральних добрив, отрутохімікатів, а також інтенсифікація сільського господарства негативно впливають на родючий шар грунту, відповідно зменшуючи кількість природних корисних грунтових властивостей, що негативно впливає на рослини, цим самим погіршуючи умови їх життєдіяльності. Унаслідок цього якість продуктів харчування погіршується через вміст шкідливих отрутохімікатів, нітратів та генетично модифікованих організмів.

Фрукти та овочі, які вирощені за інтенсивними технологіями, містять залишки понад двадцяти видів пестицидів, а м’ясо та молоко - сліди антибіотиків, гормонів, стимуляторів росту тощо. Тому споживачам важливо мати впевненість, що придбані продукти не просто безпечні, а й корисні. Внаслідок цих проблем світовий споживчий ринок стає більш органічним, а попит споживачів щодо органічних продуктів постійно зростає [9, с. 94]. Відтак, актуальним залишається питання законодавчого регулювання обліку органічного виробництва (як основного інформаційного джерела управління) на державному рівні, у тому числі і в Україні.

Аналіз останніх досліджень і публікацій. Значущість тематики наукової публікації розкривається у працях багатьох вчених-економістів. Зінчук Т.О. наголошує, що основною вимогою до органічного виробництва 
сільськогосподарської продукції $\epsilon$ вимога до умов іiі вирощування [2]. Іщенко Я.П. вивчає особливості організації обліку витрат органічного сільськогосподарського виробництва [3]. Калетнік Г.М. досліджує особливості виробництва та сертифікації органічної продукції із урахуванням досвіду США [4]. Мазур В.А. розглядає специфіку ринку органічної продукції у розрізі національного та європейського аспекту [7]. Гончарук І.В., Ковальчук С.Я., Цицюра Я.Г. та Лутковська С.М. у своїй монографії визначають основні динамічні процеси розвитку органічного виробництва в Україні [1]. Курман Т. О. вивчає проблеми законодавчого забезпечення виробництва органічної продукції [6]. Оверковська Т.К. досліджує аналіз правових ознак виробництва органічної сільськогосподарської продукції та сировини [9]. Подолянчук О.А. визначає об'єкти обліку органічного виробництва і наголошує на відсутності будь-яких напрацювань як методичного, так і нормативного забезпечення щодо їх обліку [11]. Суліменко Л.А та Киян А.В. відзначають необхідність розробки на законодавчому рівні типових форм документів та Методичних рекомендацій щодо організації обліку в умовах органічного виробництва [16].

Дослідження науковців свідчать про актуальність обраної теми, однак питання законодавчого регулювання обліку органічного виробництва в Україні залишається недостатньо розкритим і потребує вивчення.

Формулювання цілей статті. Метою наукового дослідження є розкриття питання законодавчого регулювання обліку органічного виробництва в Україні.

Виклад основного матеріалу дослідження. Сучасна популяризація здорового способу життя у світі, невід'ємною частиною якого $є$ безпечне харчування, сприяло активному збільшенню світового споживання екологічно чистої продукції. За різними експертними оцінками, найближчим часом частка екологічно чистої продукції у світовому продовольчому балансі досягне 14-30\%. Курман Т.О. у своїх дослідженнях зазначає, що до 2021 року екологічні продукти харчування мають займати четверту частину світового екологічного ринку [6, с. 154].

Зазначимо, що для кожної країни характерний свій розвиток органічного виробництва, тому є доцільним створення та дотримання власних національних державних правил на основі міжнародних стандартів. Відповідний процес імплементації забезпечує єдину систему законодавчого регулювання у сфері органічного виробництва. Дієва правова база з питань регулювання органічного виробництва в аграрному секторі економіки позитивно впливає на усіх суб'єктів господарювання (табл.1).

Зважаючи на збільшення кількості підприємств-операторів органічного виробництва, зростаючий попит на їх продукцію та збільшення зацікавлення у інформаційному забезпеченні відносно якості та відповідності продукції, як менеджменту, так і третіх осіб, відповідно зростала актуальність здійснення сертифікації органічного сільськогосподарського виробництва відповідно до міжнародних стандартів.

До 2009 року в Україні сертифікація аграрних підприємств відбувалася лише іноземними організаціями. Зважаючи на європейський досвід, в Україні за 
роки незалежності також були розроблені приватні стандарти: Стандарти органічного сільськогосподарського виробництва та маркування продукції i продуктів харчування «БІОЛан», створені на основі Базових Стандартів Міжнародної федерації органічного сільського господарства (IFOAM), Постанови Ради (ЕEC) №2092/91 стосовно органічного виробництва сільськогосподарських продуктів та Стандартів BIOSWISS Асоціації Швейцарських організацій виробників органічної продукції. А також, перша українська сертифікаційна компанія ТОВ «Органік Стандарт», що включена до офіційного переліку сертифікаційних органів, визнаних у СС та Швейцарії, яка здійснює сертифікацію продуктів рослинництва, тваринництва, бджільництва, аквакультури тощо [5, с. 69].

Таблиия 1

Вигоди для зацікавлених сторін від ухваленої нормативно-правової бази 3 питань регулювання органічного виробництва в аграрному секторі економіки

\begin{tabular}{|c|c|c|}
\hline $\begin{array}{l}\text { № } \\
\Pi / \Pi\end{array}$ & $\begin{array}{c}\text { Зацікавлені } \\
\text { сторони }\end{array}$ & Потенційні вигоди \\
\hline \multirow{7}{*}{1.} & \multirow{7}{*}{ Держава } & Стимулювання одного з найбільш пріоритетних напрямів в аграрному секторі \\
\hline & & Підвищення статусу на міжнародній арені \\
\hline & & $\begin{array}{l}\text { Позиціонування себе як країни, що стимулює суб’єкти господарювання дотримуватися } \\
\text { принципів охорони довкілля у процесі ведення землеробства }\end{array}$ \\
\hline & & Крок до європейської інтеграції \\
\hline & & $\begin{array}{l}\text { Стимулювання виробників до впровадження } \\
\text { агроекологічних програм }\end{array}$ \\
\hline & & Поява нових виробників органічних продуктів \\
\hline & & Отримання іноземних інвестицій у дану галузь \\
\hline \multirow{6}{*}{2.} & \multirow{6}{*}{ Виробники } & Технології виробництва отримують офіційний статус \\
\hline & & Поява системи компенсацій та економічного стимулювання \\
\hline & & $\begin{array}{l}\text { Понесення різного роду відповідальності для «псевдо-виробників» органічних } \\
\text { продуктів }\end{array}$ \\
\hline & & Підвищення довіри споживачів до органічних продуктів \\
\hline & & Поява нових потенційних покупців \\
\hline & & Збільшення обсягів продажу за рахунок зростання споживчого попиту \\
\hline \multirow{4}{*}{3.} & \multirow{4}{*}{ Споживачі } & Гарантування якості органічної продукції \\
\hline & & Відсутність фальсифікованої продукції маркованої як «органічна» \\
\hline & & Поінформованість про переваги органічних продуктів \\
\hline & & $\begin{array}{l}\text { Збільшення кількості виробників «органіки» сприятиме уникненню монополізації на } \\
\text { ринку }\end{array}$ \\
\hline
\end{tabular}

Джерело: сформовано автором за даними [5, с. 70].

Приватні стандарти успішно використовуються на внутрішньому ринку органічної продукції суб'єктами підприємницької діяльності, які не займаються експортними операціями. Просування екологічно чистої продукції на вітчизняному ринку потребує визначення потенційних споживачів органічної продукції, одним із напрямів виробництва $є$ продукція дитячого харчування. Прийнятий Закон України «Про дитяче харчування» від 14 вересня 2006 року № 142-V визначив стратегічні загальнодержавні пріоритети у сфері забезпечення дітей грудного та раннього віку достатнім, високоякісним та безпечним дитячим харчуванням із метою реалізації конституційних прав дитини на достатній життєвий рівень, охорону здоров'я і життя, а також організаційні, соціальні та економічні засади державної політики у цій 
cфepi [15].

Важливість даного Закону для виробників органічної продукції полягає у мотивації для подальшого розвитку в цьому напрямі, адже в більшості випадків при купівлі продуктів дитячого харчування споживачі орієнтуються на їхню корисність, якість та екологічність складових компонентів. Оскільки для ведення органічного сільськогосподарського виробництва необхідні придатні для цього землі, то у Законі йдеться про створення спеціальних сировинних зон, де існує можливість вирощування екологічно чистої продукції.

Сучасне органічне виробництво $є$ досить перспективним напрямом аграрного сектору в Україні. На законодавчому рівні закріплення змісту так званої «органіки» відбулося з прийняттям у 2013 році Закону України № 2496VIII «Про виробництво та обіг органічної сільськогосподарської продукції та сировини». 3 метою визначення вимог до організації виробництва органічної продукції і підвищення іiі конкурентоспроможності на ринках збуту, у липні 2018 року було прийнято Закон № 2496-VIII «Про основні принципи та вимоги до органічного виробництва, обігу та маркування органічної продукції», який набув чинності від 2 серпня 2019 року [12].

Закон трактує виробництво органічної продукції (сировини) як виробничу діяльність фізичних або юридичних осіб (у тому числі з вирощування та переробки), де під час такого виробництва виключається застосування хімічних добрив, пестицидів, генетично модифікованих організмів (далі - ГМО), консервантів тощо, та на всіх етапах виробництва (вирощування, переробки) застосовуються методи, принципи та правила, визначені законодавством для отримання натуральної (екологічно чистої) продукції, а також збереження та відновлення природних ресурсів [12]. Вивчаючи детальніше зазначені вище закони, можна виділити такі трактування змісту понять «органічна продукція» та «органічне виробництво» (рис. 1).

3 моменту прийняття Закону України «Про основні принципи та вимоги до органічного виробництва, обігу та маркування органічної продукції» досліджено багато питань щодо виробництва органічної продукції, проте з боку організації обліку органічного виробництва на сільськогосподарських підприємствах інформація розглянута не достатньо. Можна виділити визначені в цьому Законі терміни «органічне рослинництво», «органічне тваринництво», «органічна аквакультура» (табл. 2).

Отже, основною умовою органічного сільськогосподарського виробництва $\epsilon$ його провадження відповідно до вимог законодавства у сфері органічного виробництва, обігу та маркування органічної продукції. Загальними вимогами до органічного виробництва (ст. 14, п. 1) визначено необхідність відокремлення у часі або просторі виробництва та зберігання органічної продукції, у тому числі ведення обліку такої продукції, від виробництва та зберігання неорганічної продукції і продукції перехідного періоду [14]. Тобто на законодавчому рівні від операторів органічного виробництва вимагається організувати відокремлене ведення обліку витрат виробництва органічної, неорганічної продукції та продукції перехідного періоду, що необхідно враховувати будуючи систему об'єктів обліку витрат та 
зберігання неорганічної продукції і продукції перехідного періоду.

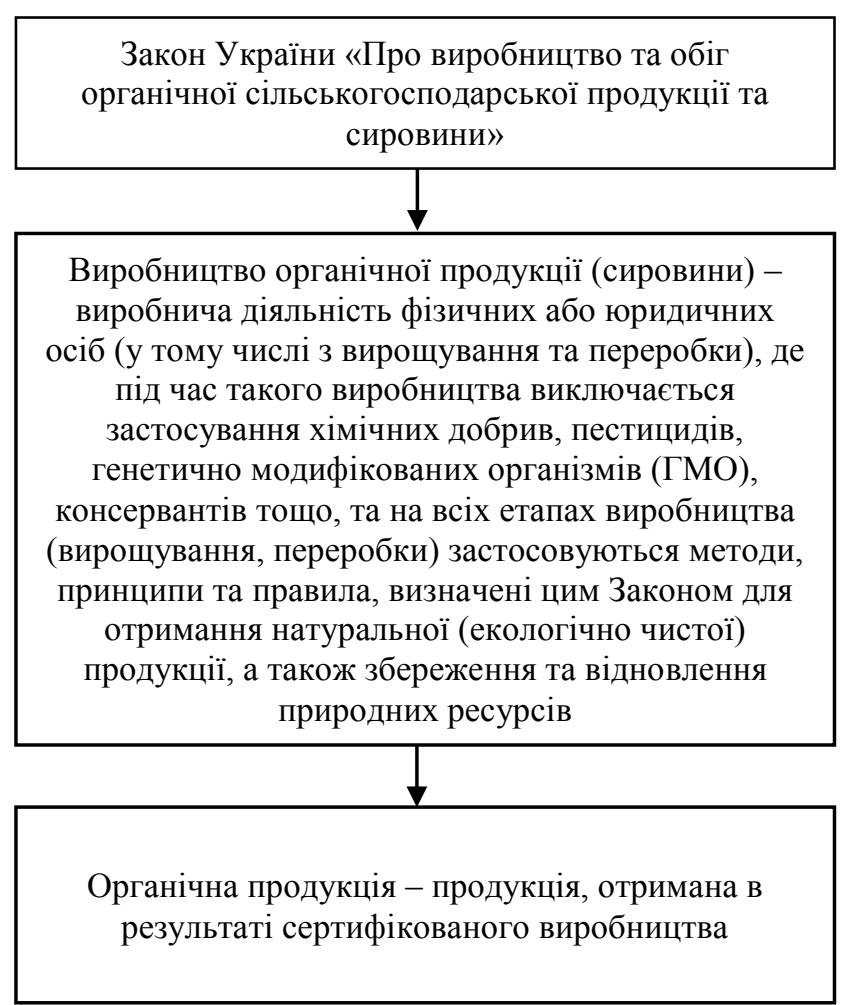

Закон України «Про основні принципи та вимоги до органічного виробництва, обігу та маркування органічної продукції»

\begin{tabular}{|c|} 
Органічне виробництво - сертифікована \\
діяльність, пов'язана з виробництвом \\
сільськогосподарської продукції (у тому числі всі \\
стадії технологічного процесу, а саме первинне \\
виробництво (включаючи збирання), підготовка, \\
обробка, змішування та пов’язані з цим процедури, \\
наповнення, пакування, переробка, відновлення та \\
інші зміни стану продукції), що провадиться із \\
дотриманням вимог законодавства у сфері \\
органічного виробництва, обігу та маркування \\
органічної продукції \\
$\quad \downarrow$ \\
Органічна продукція - сільськогосподарська \\
продукція, у тому числі харчові продукти та \\
корми, отримані в результаті органічного \\
виробництва
\end{tabular}

\section{Рис. 1. Законодавче обгрунтування сутності понять «органічна продукція» та «органічне виробництво»}

Джерело: сформовано автором за даними [11, с. 54]

Організація обліку витрат виробництва - це складний комплексний процес, що включає визначення переліку статей витрат виробництва та їх складу; об'єктів обліку витрат та об'єктів калькулювання; структури субрахунків та аналітичних рахунків прямих і непрямих витрат виробництва; порядку відображення витрат на рахунках та способів включення витрат до собівартості кожного об'єкту калькулювання; вибір методів оцінки та обліку готової продукції (основної, суміжної, побічної), обліку витрат майбутніх періодів; розробку методики і техніки обліку витрат виробництва та форм внутрішньої звітності щодо витрат та виходу продукції [3, с. 126].

Окрім того, в умовах органічного виробництва облік слід організовувати за його галузями в складі яких визначено:

- органічне рослинництво (у тому числі насінництво та розсадництво);

- органічне тваринництво (у тому числі птахівництво, бджільництво);

- органічне грибівництво (у тому числі вирощування органічних дріжджів);

- органічна аквакультура;

- виробництво органічних морських водоростей;

- виробництво органічних харчових продуктів (у тому числі органічне виноробство);

- виробництво органічних кормів;

- заготівля органічних об'єктів рослинного світу [13]. 
Таблиия 2

\section{Основні категорії органічного сільськогосподарського виробництва} відповідно до Закону України «Про основні принципи та вимоги до органічного виробництва, обігу та маркування органічної продукції»

\begin{tabular}{|c|l|}
\hline Терміни & \multicolumn{1}{|c|}{ Визначення терміну } \\
\hline $\begin{array}{c}\text { Органічне } \\
\text { рослинництво }\end{array}$ & $\begin{array}{l}\text { органічне виробництво, пов'язане з вирощуванням культурних рослин, а також } \\
\text { заготівлею об'єктів рослинного світу із дотриманням вимог законодавства у сфері } \\
\text { органінного виробництва, обігу та маркування органічної продукції. }\end{array}$ \\
\hline $\begin{array}{c}\text { Органічне } \\
\text { тваринництво }\end{array}$ & $\begin{array}{l}\text { органічне виробництво, пов'язане } 3 \text { утриманням, розведенням (виробництвом) } \\
\text { сільськогосподарських тварин (у тому числі птиці та комах) та продукції для отримання } \\
\text { продукції тваринного походження. }\end{array}$ \\
\hline $\begin{array}{c}\text { Органічна } \\
\text { аквакультура }\end{array}$ & $\begin{array}{l}\text { органічне виробництво, пов'язане із штучним розведенням, утриманням та вирощуванням } \\
\text { об'єктів аквакультури відповідно до вимог законодавства у сфері органічного } \\
\text { виробництва, обігу та маркування органічної продукції. }\end{array}$ \\
\hline
\end{tabular}

Джерело: сформовано автором за даними [3, с. 126]

Об'єктами обліку витрат в аграрному виробництві, за Методичними рекомендаціями з планування, обліку і калькулювання собівартості продукції (робіт, послуг) сільськогосподарських підприємств, $є$ культури (групи культур), види і групи тварин. Як відомо, для виробництва органічної продукції необхідно значно більше коштів, ніж для виробництва звичайної продукції, відтак, собівартість такої продукції буде вища, i, як результат, буде вища ціна. Зазначимо, що собівартість виробництва органічної продукції в Україні, як і у світі загалом, перевищує собівартість сільськогосподарської продукції, вирощеної традиційним способом. Це відбувається внаслідок особливостей процесу органічного виробництва (велика трудомісткість, необхідність виводу частини земель під пар щороку, здійснення сертифікації щодо ії̈ відповідності визначеним стандартам та нормам, яка є досить дорогою) [16].

Тому, на нашу думку, існує ряд певних факторів, вирішення яких сприятиме удосконаленню ведення обліку виробництва органічної продукції (рис. 2).

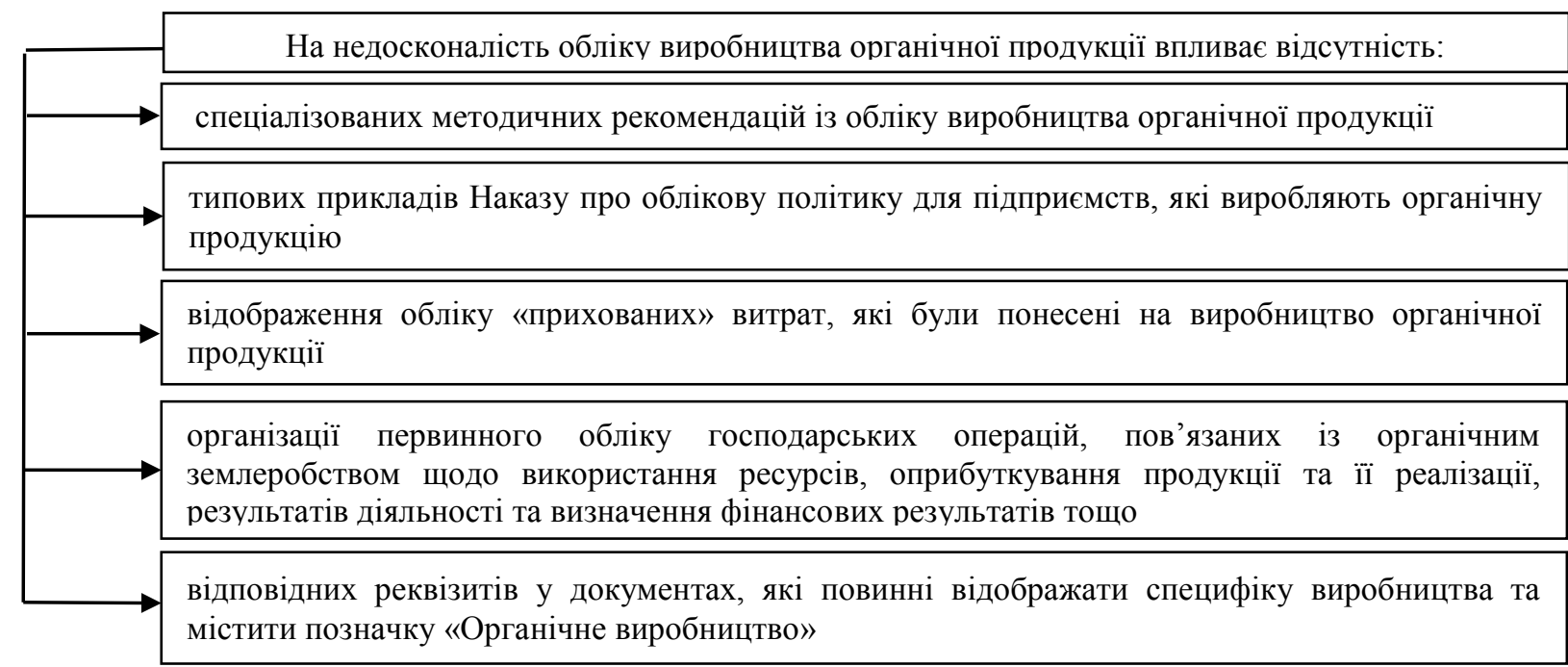

Рис. 2. Негативні фактори впливу на організацію ведення обліку органічної Джерело: сформовано автором

$$
\text { продукції }
$$


Розглядаючи процес внесення змін до облікової політики в перехідний період для підприємств, які займаються виробництвом органічної продукції, зрозуміло, що відсутність спеціалізованих методичних рекомендацій та типових прикладів Наказу про облікову політику для «органічних підприємств» значно ускладнюють організацію ведення обліку. Таким чином, формування облікової політики в аспекті виробництва органічної продукції є актуальною темою, адже спостерігається постійне збільшення кількості «органічних підприємств», i, як наслідок, зростають потреби в інформаційному забезпеченні організації ведення їх обліку.

Для ведення «органічного виробництва» дуже важливе значення має ведення та організація відповідної документації. Так, організація органічного землеробства вимагає розвитку та вдосконалення первинного обліку з метою формування додаткової облікової інформації щодо виробництва й оприбуткування готової органічної продукції для прийняття ефективних управлінських рішень.

Для вирішення проблем інформаційного забезпечення в сфері розвитку документацію:

- зберігати оригінали квитанцій/рахунків на всі куплені засоби (наприклад, добрива, пестициди, насіння) так само, як і на продану продукцію;

- вести польовий журнал (окремо для органічної та неорганічної частин господарства) та реєструвати там використання засобів (дата, діяльність, використаний засіб, кількість) та дати посіву і збору врожаю;

- мати зведені дані використання засобів захисту рослин і добрив по кожному полю за рік (що вносилося, в якій кількості та під яку культуру);

- мати план сівозміни, карту полів (де буде відмічено розміри полів, відповідна нумерація, поля з позначенням можливого ризику перенесення 3 боку сусідніх полів) господарства, схеми виробничих приміщень;

- вести реєстр збору врожаю, мати записи із зберігання та реалізації продукції Ці записи повинні відображуватися у балансі продукції у господарстві [16].

У Законі України «Про основні принципи та вимоги до органічного виробництва, обігу та маркування органічної продукції» [14] взагалі відсутні вказівки щодо організації ведення обліку органічного виробництва, лише $\epsilon$ згадка, що його потрібно здійснювати. Розвиток органічного 
сільськогосподарського виробництва та формування ринку органічних продуктів в Україні значно сповільнюється через недосконалу нормативноправову базу, відсутність належного інформаційного забезпечення, зокрема типових документів із обліку витрат та виходу органічної продукції, також через недостатньо розвинуту мережу каналів збуту органічної продукції. 3 огляду на це, було б доцільно надати рекомендації Міністерству аграрної політики та продовольства України розробити типові форми документів та Методичні рекомендації щодо організації обліку в умовах органічного виробництва.

Висновки. Незважаючи на стрімкий розвиток органічного виробництва в Україні існує ряд певних перешкод, які суттєво сповільнюють розвиток органічного сільськогосподарського виробництва та формування ринку органічних продуктів у цілому. Проведені нами дослідження вказують на недосконалість чинного законодавства з питань обліку виробництва органічної продукції, тому пропонуємо внести у законодавство основні положення щодо ведення обліку органічного виробництва та створення типових нормативних документів для реєстрації пов'язаних із ним витрат.

Недосконала нормативно-правова база та відсутність належного інформаційного забезпечення негативно впливають на роботу «органічних підприємств». Пропонуємо відображати облікові дані про витрати на органічне виробництво та наявність i рух органічної продукції у фінансовій, управлінській та статистичній звітностях із метою забезпечення інформативності як внутрішніх, так i зовнішніх користувачів. Враховуючи стратегічні перспективи розвитку органічного сільськогосподарського виробництва в Україні, як складової концепції сталого розвитку, необхідно розробити єдину систему інформатизації інституцій суспільства для можливості оцінки стану органічного виробництва, формування стратегії його розвитку та для забезпечення ефективного управління цими процесами.

Перспективними напрямами подальших досліджень $є$ розробка методичних підходів до організації та методики ведення обліку виробництва органічної продукції; розробка методики обліку витрат та калькулювання собівартості органічної сільськогосподарської продукції; методики обліку та розподілу загальновиробничих витрат.

\section{Список використаних джерел}

1. Гончарук I.В., Ковальчук С.Я., Цицюра Я.Г., Лутковська С.М. Динамічні процеси розвитку органічного виробництва в Україні: монографія. Вінниця: Твори. 2020. 472 с.

2. Зінчук Т.О. Витоки та підходи до формування категоріального апарату «Органічне виробництво»: Європейський i світовий досвід. URL: http://znau.edu.ua/media/nauka_innovation/organic/Organic_20132.pdf (дата звернення: 10.06.2021).

3. Іщенко Я.П. Особливості організації обліку витрат органічного сільськогосподарського виробництва. Економіка, фінанси, менеджмент: актуальні питання науки і практики. 2019. № 7. С. 122-132. 
4. Калетнік Г.М., Пришляк Н.В. Виробництво та сертифікація органічної продукції: досвід США. Економіка, фінанси, менеджмент: актуальні питання науки і практики. 2017. № 9. С. 122-132.

5. Кутаренко Н.Я. Правове регулювання органічного виробництва сільськогосподарської продукції в Україні. Агросвіт. 2019. № 22. С. 66-73.

6. Курман Т.О. Проблеми законодавчого забезпечення виробництва органічної продукції тваринництва. Підприємництвво, господарство $і$ право. 2018. № 12. C. 153-157.

7. Мазур В.А., Ковальчук С.Я. Специфіка ринку органічної продукції: національний та європейський аспект. Економіка, фінанси, менеджмент: актуальні питання науки і практики. 2018. № 4. С. 7-18.

8. Мельничук Я.П. Документальне оформлення витрат і виходу продукції рослинництва органічного походження. Вісник Житомирського державного технічного університету. 2016. № 2 (76). С. 27-32.

9. Оверковська Т.К. Правові ознаки органічного виробництва сільськогосподарської продукції в Україні. Підприємство, господарство $i$ право. 2017. № 11. С. 94-98.

10. Органічна Україна в інфографіці. URL: http://agroportal.ua/ua/publishing/infografika/organicheskaya-ukraina-v-info-grafike (дата звернення: 10.06.2021).

11. Подолянчук О.А. Сутність та основи обліку органічної продукції. Агросвіт. 2019. № 16. С. 51-57.

12. Про виробництво та обіг органічної сільськогосподарської продукції та сировини: Закон України від 03.09.2013 p. № 425-VII. URL: http:/ /zakon.rada.gov.ua/laws/show/425-18 (дата звернення: 10.06.2021).

13. Про затвердження Порядку (детальних правил) органічного виробництва та обігу органічної продукції: Постанова Кабінету Міністрів України від 23.10.2019 p. № 970 https://zakon.rada.gov.ua/laws/show/970-2019$\%$ D0\%BF\#Text (дата звернення: 10.06.2021).

14. Про основні принципи та вимоги до органічного виробництва, обігу та маркування органічної продукції: Закон України від 10.07.2018 р. № 2496-VIII. URL: http://zakon.rada.gov.ua/ laws/show/2496-19 (дата звернення: 15.02.2021).

15. Про дитяче харчування: Закон України від 14.09.2006 року № 142-V. URL: https://zakon.rada.gov.ua/laws/show/142-16 (дата звернення: 10.06.2021).

16. Суліменко Л.А., Киян А.В. Особливості бухгалтерського обліку в умовах органічного виробництва продукції рослинництва. URL: http://ir.znau.edu.ua/bitstream/123456789/8422/1/Organik_2017_346-351.pdf (дата звернення: 10.06.2021).

\section{References}

1. Honcharuk, I.V., Kovalchuk, S.Y., Tsitsyura, Y.G., \& Lutkovskaya, S.M. (2020). Dunamichni procesu rozvutky organichnogo vurobnuctva v Ukraini [Dynamic processes of organic production development in Ukraine]. Vinnytsia: Tvoru [in Ukrainian].

2. Zinchuk, T. Vutoku ta pidhodu do formyvanna kategorialnogo aparaty 
«Organicne vurobnuctvo»: Evropeyskiy i svitovyi dosvid [Origins and approaches to the formation of the categorical apparatus «Organic production»: European and world experience]. znau.edu.ua. Retrieved from: http://znau.edu.ua/media/nauka_ innovation/organic/Organic_20132.pdf [in Ukrainian].

3. Ishchenko, Ya. (2019). Osobluvosti organizacii obliky c organichnogo silskogospodarskogo virobnuctva [Features of the organization of the account of expenses of organic agricultural production]. Ekonomika, finansy, menedzhment: aktualni pytannia nauky i praktyky - Economy, finances, management: topical issues of science and practice activity, 7, 122-132 [in Ukrainian].

4. Kaletnik, H.M., \& Pryshliak, N.V. (2017). Vyrobnytstvo ta sertyfikatsiia orhanichnoi produktsii: dosvid SShA [Production and Certification of Organic Products: US Experience] Ekonomika, finansy, menedzhment: aktualni pytannia nauky i praktyky - Economy, finances, management: topical issues of science and practice activity, 9, 7-22 [in Ukrainian].

5. Kutarenko, N.Ya. (2019). Pravove regylyvannia organichnogo vurobnuctva silskogospodarskoi prodykcii $\mathrm{v}$ Ukraini [Legal regulation of organic production of agricultural products in Ukraine]. Ahrosvit - Agrosvit, 22, 66-73 [in Ukrainian].

6. Kurman, T.O. (2018). Problemu zakonodavchogo zabezpechenny virobnuctva organichnoi produkcii tvarunnuctva [Problems of legislative support for the production of organic livestock product]. Pidpryiemnytstvo, hospodarstvo i pravo - Entrepreneurship, economy and law, 12, 153-157 [in Ukrainian].

7. Mazur, V.A., \& Kovalchuk, S.Ya. (2018). Spetsyfika rynku orhanichnoi produktsii: natsionalnyi ta yevropeiskyi aspekt [Specificity of the organic products market: national and European aspect]. Ekonomika, finansy, menedzhment: aktualni pytannia nauky i praktyky - Economy, finances, management: topical issues of science and practice, 4, 7-18 [in Ukrainian].

8. Melnychuk, Ya. (2016). Dokymentalne oformlennia vutrat i vyhody prodykcii roslunnuctva organichnogo pohodjennia [Documentation of costs and output of products of organic origin]. VISNYK Zhytomyrskogo derzhavnogo tehnichnogo yniversutety - Bulletin of Zhytomyr State Technical University, 2 (76), 27-32 [in Ukrainian].

9. Overtkovskaya, T.K. (2017). Pravovi oznaku organichnogo vurobnuctvasilskogospodarskoi produkcii $\mathrm{v}$ Ukraini [Legal features of organic production of agricultural products in Ukraine]. Pidpryiemnytstvo, hospodarstvo $i$ pravo - Enterprise, economy and law, 11, $94-98$ [in Ukrainian].

10. Orhanichna Ukraina $\mathrm{v}$ infohrafitsi [Organic Ukraine in infographics]. agroportal.ua. Retrieved from http://agroportal.ua/ua/publishing/ infografika/organicheskaya-ukraina-v-infografike/ \#Text [in Ukrainian].

11. Podolyanchuk, O. (2019). Sytnist ta osnovu obliky organichnoi prodykcii [The essence and basics of accounting for organic products]. Ahrosvit-Agrosvit, 16, 51-57 [in Ukrainian].

12. Zakon Ukrainy «Pro vurobnuctvo ta obig organichnoi silskogospodarskoi prodykcii ta surovunu» vid 03.09.2013 roku № 425-VII. [Law of Ukraine on the production and circulation of organic agricultural products and raw materials from September 03 2013, №425-VII]. (2013). zakon.rada.gov.ua. Retrieved from: http:/ 
/zakon.rada.gov.ua/laws/show/425-18 [in Ukrainian].

13. Postanova Kabinetu Ministriv Ukrainy «Pro zatverdgennia poriadky (detalnuh pravul) organichnogo vurobnuctva ta obigy organichnoi prodykcii» vid 23.10.2019 roku № 970 [Resolution of the Cabinet of Ministers of Ukraine on approval of the Procedure (detailed rules) for organic production and circulation of organic products from October 23 2019, № 970]. (2019). zakon.rada.gov.ua. Retrieved from: https://zakon.rada.gov.ua/laws/show/970-2019-\%D0\%BF\#Text [in Ukrainian].

14. Zakon Ukrainy «Pro osnovni pryntsypy ta vymohy do orhanichnoho vyrobnytstva, obihu ta markuvannia orhanichnoi produktsii» vid 10.07.2018 roku №2496-VIII [Law of Ukraine on Basic Principles and Requirements for Organic Production, Turnover and Marking of Organic Products from July 102018 № 2496VIII]. (2018). zakon.rada.gov.ua. Retrieved from: http://zakon.rada.gov.ua/ laws/show/2496-19 \#Text [in Ukrainian].

15. Zakon Ukrainy «Pro dutiache harchyvannia» vid 14.09.2006 roku №142V. [Law of Ukraine about baby food from September 142019 №142-V]. (2019). \#Text [in Ukrainian].

16. Sulimenko, L., \& Kyian, A. (2017). Osobluvosti byhgalterskogo obliky v ymovah organichnogo vurobnuctstva produkcii roslunnuctva [Features of accounting in the conditions of organic production of crop production]. (n.d.). ir.znau.edu.ua. Retrieved from: http://ir.znau.edu.ua/bitstream/123456789/ 8422/1/Organik_2017_346*351.pdf \#Text [in Ukrainian].

\section{Відомості про автора}

МАРКЕВИЧ Людмила Станіславівна - аспірантка кафедри обліку та оподаткування в галузях економіки, Вінницький національний аграрний університет (21008, м. Вінниця, вул. Сонячна, 3, e-mail: mila.mark21@gmail.com).

MARKEVYCH Lyudmyla Stanislavivna - Postgraduate Student of the Department of Accounting and Taxation in the Fields of Economics, Vinnytsia National Agrarian University (21008, Vinnytsia, 3, Soniachna Str., e-mail: mila.mark21@gmail.com).

МАРКЕВИЧ Людмила Станиславовна - аспирантка кафедры учета и налогообложения в отраслях экономики, Винницкий национальный аграрный университет (21008, г. Винница, ул. Солнечная, 3, e-mail: mila.mark21@gmail.com). 